\title{
Microbial diversity of saline environments: searching for cytotoxic activities
}

\author{
Carolina Díaz-Cárdenas ${ }^{1}$, Angela Cantillo², Laura Yinneth Rojas³ ${ }^{3}$ Tito Sandoval ${ }^{3}$, Susana Fiorentino ${ }^{3}$, \\ Jorge Robles ${ }^{4}$, Freddy A. Ramos ${ }^{5}$, María Mercedes Zambrano ${ }^{2}$ and Sandra Baena ${ }^{1^{*}}$ (1)
}

\begin{abstract}
In order to select halophilic microorganisms as a source of compounds with cytotoxic activities, a total of 135 bacterial strains were isolated from water and sediment samples collected from the Zipaquirá salt mine in the Colombian Andes. We determined the cytotoxic effects of 100 crude extracts from 54 selected organisms on the adherent murine mammary cell carcinoma 4T1 and human mammary adenocarcinoma MCF-7 cell lines. These extracts were obtained from strains of Isoptericola, Ornithinimicrobium, Janibacter, Nesterenkonia, Alkalibacterium, Bacillus, Halomonas, Chromohalobacter, Shewanella, Salipiger, Martellela, Oceanibaculum, Caenispirillum and Labrenzia. The extracts of 23 strains showed an $\mathrm{IC}_{50}$ of less than $100 \mathrm{\mu g} \mathrm{mL} \mathrm{mL}^{-1}$. They were subsequently analyzed by LC/MS allowing dereplication of 20 compounds. The cytotoxic effect was related to a complex mixture of diketopiperazines present in many of the extracts analyzed. The greatest cytotoxic activity against both of the evaluated cell lines was obtained from the chloroform extract of Labrenzia aggregata USBA 371 which had an $\mathrm{IC}_{50}<6 \mu \mathrm{g} \mathrm{mL} \mathrm{L}^{-1}$. Other extracts with high levels of cytotoxic activity were obtained from Bacillus sp. $\left(\mathrm{IC}_{50}<50 \mu \mathrm{g} \mathrm{mL}^{-1}\right)$ which contained several compounds such as macrolactin $L$ and A, 7-O-succinoylmacrolactin $\mathrm{F}$ and iturin. Shewanella chilikensis USBA 344 also showed high levels of cytotoxic activity against both cell lines in the crude extract: an $\mathrm{IC}_{50}<15 \mu \mathrm{g} \mathrm{mL} \mathrm{L}^{-1}$ against the 4T1 cell line and an $\mathrm{IC}_{50}<68 \mu \mathrm{g} \mathrm{mL}{ }^{-1}$ against the MCF-7 cell line. Nesterenkonia sandarakina CG 35, which has an $\mathrm{IC}_{50}$ of $118 \mu \mathrm{g} \mathrm{mL} \mathrm{L}^{-1}$ against $4 \mathrm{~T} 1$, is a producer of diketopiperazines and 1-acetyl- $\beta$-carboline. Also, Ornithinimicrobium kibberense CG 24 , which has $\mathrm{IC}_{50}<50 \mathrm{\mu g} \mathrm{mL}^{-1}$, was a producer of diketopiperazines and lagunamycin. Our study demonstrates that these saline environments are habitats of halophilic and halotolerant bacteria that have previously unreported cytotoxic activity.
\end{abstract}

Keywords: Phylogenetic diversity, Halophilic bacteria, Cytotoxic activity, Secondary metabolism

\section{Introduction}

Saline environments are usually defined as those containing salt concentrations similar to seawater $(\sim 3.5 \%$ $(w / v)$ total dissolved salts) whereas hypersaline environments contain higher salt concentrations and these environments are largely used for the study of the microbial diversity and ecology (Ventosa et al. 2014). Halophiles have attracted the interests of researchers because of their adaptability to a wide range of salinities as well as

\footnotetext{
*Correspondence: baena@javeriana.edu.co

${ }^{1}$ Unidad de Saneamiento y Biotecnología Ambiental, Departamento de Biología, Pontificia Universidad Javeriana, POB 56710, Bogotá DC, Colombia

Full list of author information is available at the end of the article
}

their potentially promising applications. They are sources of compatible solutes, stable enzymes (DNAses, lipases, amylases and proteases), bacteriorhodopsin, polymers, $\beta$-carotene and other organic substances of interest (Chen et al. 2010; Oren 2010; Braña et al. 2015; da Silva et al. 2015).

These microorganisms have been also considered as a potential source of bioactive compounds. Several antitumor and antimicrobial substances have already been isolated from moderately and extremely halophilic microorganisms including archaeal proteinaceous antimicrobials (i.e. halocins) that have been isolated from several extremely halophilic archaea such as Natrinema sp. (Karthikeyan et al. 2013) and Haloferax mediterranei 
(O'Connor and Shand 2002). Other examples are pigments such as prodigiosin isolated from Vibrio spp., that exhibit antimicrobial activity (Gallardo et al. 2016). Lipopeptides, polyketides, terpenes, macrolactins from diverse microorganisms such as Saccharothrix sp., Nocardiopsis sp., and Bacillus spp. (Gan et al. 2015; Son et al. 2016; Kim et al. 2017) and diketopiperazines (DKPs) from Streptomyces spp., Bacillus spp. and Nocardiopsis spp. (Raju et al. 2009; Fu et al. 2011; Yonezawa et al. 2011; Gu et al. 2013). Thus, the saline environments could be largely underexplored ecological niches for the discovery of bioactive metabolites and these halophilic microorganisms are potential sources for a broad range of new therapeutic compounds (Demain 2014). The current estimate that $90 \%$ of the biosynthetic capacity of microorganisms is yet to be discovered highlights the importance of research in microbial diversity and in the discovery of bioactive principles as keys to unlocking the metabolic potential of microbes (Walsh and Fischbach 2010).

The aim of this study was to generate information on the cytotoxic potential of extracts and compounds produced by halophilic and halotolerant organisms isolated from unexplored Colombian rock salt and saline spring environments. Thus, in this study, halophilic microorganisms were isolated from hypersaline environments at the Zipaquirá salt mine, located in the eastern Andean Mountain range. They were then analyzed for their capacities to produce cytotoxic compounds under several salt concentrations.

\section{Materials and methods}

\section{Zipaquirá salt mine: site description and sampling}

Samples of water, sediment, brine and solid (rock salt) were collected in $500 \mathrm{~mL}$ sterile glass and plastic bottles from six sampling points during three sampling events at the Zipaquirá salt mine in Colombia $\left(5^{\circ} 01^{\prime} 06.18^{\prime \prime} \mathrm{N}\right.$ and $\left.74^{\circ} 0^{\prime} 13.63^{\prime \prime} \mathrm{W}\right)$ at 2656 m.a.s.l. The samples were used to inoculate basal salt medium, to which several carbon sources were added. The samples were carefully stored at $4{ }^{\circ} \mathrm{C}$ and transported to the laboratories prior to analysis. The samples were used for enrichment on the following day.

For physical-chemical analysis, $5 \mathrm{~L}$ of water from each sampling point were collected. The temperature and $\mathrm{pH}$ analyses were performed in situ using a Hach $\mathrm{pH}$ meter. The analysis of calcium $\left(\mathrm{Ca}^{2+} \mathrm{mg} \mathrm{L}^{-1}\right)$, total organic carbon ( $\left.\mathrm{mg} \mathrm{L}^{-1}\right)$, chlorides $\left(\mathrm{Cl}^{-} \mathrm{mg} \mathrm{L}{ }^{-1}\right)$, total phosphorous $\left(\mathrm{PO}_{4}{ }^{3-} \mathrm{mg} \mathrm{L}^{-1}\right)$, total iron $\left(\mathrm{Fe} \mathrm{mg} \mathrm{L}{ }^{-1}\right)$, magnesium $\left(\mathrm{Mg}^{2+} \mathrm{mg} \mathrm{L}^{-1}\right)$, manganese $\left(\mathrm{Mn}^{2+} \mathrm{mg} \mathrm{L}{ }^{-1}\right)$, nitrates $\left(\mathrm{N}-\mathrm{NO}_{3} \mathrm{mg} \mathrm{L}^{-1}\right)$, ammoniacal nitrogen $\left(\mathrm{N}-\mathrm{NH}_{4} \mathrm{mg} \mathrm{L}^{-1}\right)$, potassium $\left(\mathrm{K}^{+} \mathrm{mg} \mathrm{L}^{-1}\right)$, salinity (conductivity $\mathrm{mS} \mathrm{cm}^{-1}$ ), sodium $\left(\mathrm{Na}^{+} \mathrm{mg} \mathrm{L}^{-1}\right)$, sulfate $\left(\mathrm{SO}_{4}{ }^{2-} \mathrm{mg} \mathrm{L}^{-1}\right)$ and sulfites
$\left(\mathrm{SO}_{3}{ }^{2-} \mathrm{mg} \mathrm{L}{ }^{-1}\right)$ was performed using standard methods (APHA/AWWA/WEF 2012).

\section{Strains}

Both halophilic microorganisms isolated from Zipaquirá salt mine and other previously isolated strains were used for screening in this study. These previously isolated strains were obtained in a previous study from two saline springs in the Central Mountain Range of the Colombian Andes and are part of our collection of microorganisms (Díaz-Cárdenas and Baena 2015): Oceanibaculum indicum USBA 36, Caenispirillum bisanense USBA 85, Shewanella chilikensis USBA 344 and Labrenzia aggregata USBA 371. All of the strains evaluated for the cytotoxic screenings were deposited in the Colección de microorganismos de la Pontificia Universidad Javeriana (WDCM857).

\section{Isolation and enrichment of halophilic microorganisms}

In order to isolate halophilic microorganisms the following media were used. (1) Actinomycete isolation agar (per liter of distilled water): $4 \%(\mathrm{w} / \mathrm{v}) \mathrm{NaCl}, 2.0 \mathrm{~g}$ of sodium caseinate, $0.1 \mathrm{~g}$ of asparagine, $4.0 \mathrm{~g}$ of sodium propionate, $0.5 \mathrm{~g}$ of $\mathrm{K}_{2} \mathrm{HPO}_{4}, 0.1 \mathrm{~g}$ of $\mathrm{MgSO}_{4} \cdot 7 \mathrm{H}_{2} \mathrm{O}, 0.1 \mathrm{~g}$ of $\mathrm{FeSO}_{4}, 5.0 \mathrm{~g}$ of glycerol and $15 \mathrm{~g}$ of agar (Sigma). (2) Halophilic medium (HM) (per liter of distilled water): 10 or $4 \%(\mathrm{w} / \mathrm{v}) \mathrm{NaCl}, 2.0 \mathrm{~g}$ of $\mathrm{KCl}, 1.0 \mathrm{~g}$ of $\mathrm{MgSO}_{4}, 0.36 \mathrm{~g}$ of $\mathrm{CaCl}_{2} 2 \mathrm{H}_{2} \mathrm{O}, 0.23 \mathrm{~g}$ of $\mathrm{NaBr}, 0.06 \mathrm{~g}$ of $\mathrm{NaHCO}_{3}$, trace $\mathrm{FeCl}_{3}, 10.0 \mathrm{~g}$ of yeast extract (Difco), $5.0 \mathrm{~g}$ of peptone (Difco) and $1.0 \mathrm{~g}$ of glucose (pH 7.5) (Ventosa Ucero et al. 1982). (3) M63 medium (per liter of distilled water): $13.6 \mathrm{~g}$ of $\mathrm{KH}_{2} \mathrm{PO}_{4}, 2 \mathrm{~g}$ of $\left(\mathrm{NH}_{4}\right)_{2} \mathrm{SO}_{4}, 0.5 \mathrm{~g}$ of $\mathrm{FeSO}_{4} \cdot 7 \mathrm{H}_{2} \mathrm{O}$, $0.24 \mathrm{~g}$ of $\mathrm{MgSO}_{4} \cdot 7 \mathrm{H}_{2} \mathrm{O}$ and $4 \mathrm{~g}$ of glucose (Takashina et al. 1994). (4) Water from the sampling points filtered through $47 \mathrm{~mm}$ diameter filters with a pore size of $0.45 \mu \mathrm{m}$ (GTTP, Millipore, Billerica, MA, USA) and then sterilized at $121^{\circ} \mathrm{C}$ and 15 psi for $30 \mathrm{~min}$. This water was supplemented with $1 \mathrm{ml} \mathrm{L}^{-1}$ of the oligoelement solution SL10 (Widdel et al. 1983) and either $0.1 \%(\mathrm{w} / \mathrm{v})$ casamino acids, $10 \mathrm{mM}$ glycerol or $4 \mathrm{mM}$ acetic acid as the carbon source. The culture medium $\mathrm{pH}$ was adjusted to 6.0-7.0 with $10 \% \mathrm{NaOH}(\mathrm{w} / \mathrm{v})$ (Merck), to take into account the in situ $\mathrm{pH}$ at the sampling points. Enrichments were performed by inoculating $1 \mathrm{~mL}$ of sample from each of the six sampling points into tubes containing $5 \mathrm{~mL}$ of culture media and then incubating the tubes at room temperature $\left(22^{\circ} \mathrm{C} \pm 3\right)$ in the dark and without agitation until growth was observed. Microbial growth was inspected daily for 2 weeks by light microscopy using a Nikon phase contrast microscope (Nikon i50 Nikon, Melville, NY, USA). After confirmation of growth, tenfold serial dilutions were prepared and inoculated into tubes with $5 \mathrm{~mL}$ of culture medium, and the last positive serial dilution 
was used to inoculate plates containing enrichment medium fortified with $2 \%(\mathrm{w} / \mathrm{v})$ agar (Sigma). The tubes were incubated under the same conditions described above. Cells with different morphologies and appearances were transferred to new culture plates to obtain pure cultures. The isolates were purified by repeated growth on solid media and preserved with $20 \%$ (v/v) glycerol at $-80{ }^{\circ} \mathrm{C}$.

Solid samples (salt rock) were first surface-sterilized by immersing $200 \mathrm{~g}$ of the sample in ethanol followed by flaming. Each $200 \mathrm{~g}$ sample was then introduced into a 250-mL Erlenmeyer flask with $100 \mathrm{~mL}$ of liquid medium supplemented with various $\mathrm{NaCl}$ concentrations $(5,8$, 10 and $20 \% \mathrm{w} / \mathrm{v}$ ) and then incubated in the dark without stirring for 10 days at room temperature. Serial dilutions of these 10 day cultures were then plated onto TSA (Merck) and HM halophilic medium supplemented with 5 or $8 \%(\mathrm{w} / \mathrm{v}) \mathrm{NaCl} ; 10$ day cultures in 10 and $20 \%(\mathrm{w} / \mathrm{v})$ $\mathrm{NaCl}$ were plated directly onto solid media $(100 \mu \mathrm{L})$. After 5 days of incubation at room temperature in the dark, colonies with morphological and pigment differences were selected, and successive passages were conducted until pure strains were obtained.

The isolated strains were grown in TSB (Merck), marine broth (Difco) or modified marine broth (Difco) supplemented with either $0.1 \%(\mathrm{w} / \mathrm{v})$ casamino acids or $5 \mathrm{mM}$ glucose, and 3, 5 or $8 \%(\mathrm{w} / \mathrm{v}) \mathrm{NaCl}$ to adjust the salinity.

\section{Sequence analysis of the $16 \mathrm{~S}$ rRNA gene and phylogenetic reconstruction}

DNA was extracted using the Wizard ${ }^{\circledR}$ Genomic DNA kit (Promega cat \#A1120) from $10 \mathrm{~mL}$ of an exponentially growing microbial culture at $8000 \times g$ for $10 \mathrm{~min}$ or purified from colonies resuspended in $10 \mathrm{mM}$ Tris$\mathrm{HCl}$ and 0.7\% SDS (Cayol et al. 1995). The 16S rRNA gene was amplified using the universal primers $27 \mathrm{~F}$ (5'-AGAGTTTGATCMTGGCTCAG-3') and 1492R (5'-GGTTACCTTGTTACGACTT-3') (Lane 1991) for bacteria and 344F (5'-ACKGCTCAGTAACACGT-3') (Raskin et al. 1994) and 915R (5'-GTGCTCCCCCGCCAATTCCT-3') (Stahl and Amann 1991) for archaea. All PCRs (in a $50-\mu \mathrm{L}$ total volume reaction) contained $<0.5 \mu \mathrm{g}$ of DNA template, $0.2 \mu \mathrm{M}$ of each primer, $0.2 \mathrm{mM}$ dNTPs, $1.5 \mathrm{mM} \mathrm{MgCl}{ }_{2}, 1 \mathrm{X}$ Buffer and $1.25 \mathrm{U}$ of GoTaq ${ }^{\circledR}$ DNA Polymerase (Promega). The PCR conditions were $94{ }^{\circ} \mathrm{C}$ for $2 \mathrm{~min}, 35$ cycles at $94{ }^{\circ} \mathrm{C}$ for $30 \mathrm{~s}, 55{ }^{\circ} \mathrm{C}$ for $45 \mathrm{~s}$, and $72{ }^{\circ} \mathrm{C}$ for 1 min followed by a final elongation step of $10 \mathrm{~min}$ at $72{ }^{\circ} \mathrm{C}$. Sequencing was performed using an ABI PRISM ${ }^{\circledR} 3500$ (Laboratorio de secuenciación de ADN, Universidad de Los Andes, Bogotá, Colombia) and an ABI PRISM ${ }^{\circledR}$ 3730XL Analyzer (Macrogen Inc., South Korea). Raw sequence data were imported into BioEdit, version 7.2.5, sequence editor (Hall 1999) and corrected manually for errors. Sequences were compared against sequences of type strains using RDP release 11 (https://rdp.cme.msu.edu/).

\section{Nucleotide sequence accession numbers}

The 16S rRNA gene sequences of the novel and previously isolated strains were deposited in GenBank under the accession numbers MF197926-MF197981, MF506732-MF506815.

\section{Cytotoxic activity screening assays}

Cultures were started with a saturated (24-120 h) culture, diluted to $10^{5} \mathrm{CFU}$ and inoculated 1:100 into fresh medium, and cultured under the conditions described in Additional file 1: Table S1. The culture media used were marine broth (Difco), modified marine broth with $1 \%(\mathrm{w} / \mathrm{v})$ casamino acids, $5 \mathrm{mM}$ glucose, TSB (Merck) and TSB supplemented with $3 \%(\mathrm{w} / \mathrm{v}), 4 \%(\mathrm{w} / \mathrm{v}), 5 \%$ $(\mathrm{w} / \mathrm{v})$ or $8 \%(\mathrm{w} / \mathrm{v}) \mathrm{NaCl}$. All cultures were grown in duplicate.

\section{Preparation of crude extracts}

Microbial cultures were centrifuged at $9000 \times g$ at $4{ }^{\circ} \mathrm{C}$ for $20 \mathrm{~min}$, and cell-free supernatants were sequentially extracted three times with chloroform and ethyl acetate at a 1:1 ratio. The extracts were evaporated under reduced pressure using a Buchi Rotavapor R114 (Buchi, Switzerland) and then stored at $-20{ }^{\circ} \mathrm{C}$ in amber glass vials prior to use. Uninoculated culture medium was processed as a negative control. The chloroform extracts were resuspended in dimethyl sulfoxide (DMSO), and the ethyl acetate extracts were resuspended in ethanol at final concentrations of $25 \mathrm{mg} \mathrm{mL}^{-1}$ (stock solution). Subsequently, the samples were diluted (from 250 to $31 \mu \mathrm{g} \mathrm{mL}^{-1}$ ) for evaluation of cytotoxic activity.

\section{Cytotoxic activity screening}

The cytotoxic activity of the extracts was determined using the neutral red technique (Repetto et al. 2008). Briefly, the adherent 4T1 (mouse mammary tumor) and MCF-7 (human mammary adenocarcinoma) cell lines were cultured in RPMI medium supplemented with $10 \%$ fetal bovine serum in 96-well plates at a density of $3 \times 10^{3}$ cells well $^{-1}$. The plates were incubated for $12 \mathrm{~h}$ at $37{ }^{\circ} \mathrm{C}$ in $5 \% \mathrm{CO}_{2}$ to allow monolayer formation. Selection of promising strains was performed using four dilutions ranging from 250 to $31.25 \mu \mathrm{g} \mathrm{mL}^{-1}$. The solvent used in the reconstitution of the extract (ethanol or DMSO) was evaluated as a negative control for each test in the same volume as the extracts. Doxorubicin at a maximum concentration of $5 \mu \mathrm{M}$ was used as a positive control. In addition, untreated cell controls, cell-free treatments and 
a culture medium control were included for each extract. These analyses were performed in duplicate.

After $48 \mathrm{~h}$ of treatment, two washes were performed with $1 \mathrm{X}$ PBS, the neutral red reagent was added to each well and the plates were incubated for $3 \mathrm{~h}$. After incubation, two washes were performed with PBS. Finally, a bleach solution (1\% (v/v) glacial acetic acid, $50 \%(\mathrm{v} / \mathrm{v})$ ethanol and $49 \%(\mathrm{v} / \mathrm{v})$ distilled water) was added to each well and stirred for $20 \mathrm{~min}$ before the absorbance was read at $540 \mathrm{~nm}$ (Multiskan ${ }^{\text {TM }}$ FC microplate photometer) (Repetto et al. 2008).

Inhibitory concentration $50\left(\mathrm{IC}_{50}\right)$ values were defined as the concentration of the extracts that generated $50 \%$ inhibition of tumor cell growth. To calculate the $\mathrm{IC}_{50}$, the same procedure described for the initial screening was performed using eight decreasing concentrations starting at $250 \mu \mathrm{g} \mathrm{mL}^{-1}$. The positive and negative controls were the same as those used for the initial screening. The calculation was performed using a non-linear regression method of Log (concentration) vs. percentage inhibition using algorithms with three or four parameters according to the behavior of the treatment. These analyses were conducted using GraphPad Prism 6.0.

\section{Fractionation and metabolomics evaluation}

Crude extracts with cytotoxic activity (100 mg) were fractionated using cartridges (Hypersep DIOL-Thermo Scientific) and solvents with increasing polarity, starting with hexane and ending with methanol. Twelve fractions were obtained as follows: F1.1 and F 1.2. (100\% hexane), F2.1 and F2.2 (hexane/ethyl acetate, 8:2), F3.1 and F3.2 (hexane/ethyl acetate 1:1), F4.1 and F4.2 (100\% ethyl acetate), F5.1 and F5.2 (ethyl acetate/methanol, 1:1) and F6.1 and F6.2 (100\% methanol). The fractions were evaporated at room temperature and stored at $-20{ }^{\circ} \mathrm{C}$ in amber glass vials prior to use.

\section{LC/MS analysis of active extracts and fractions}

Selected samples were analyzed by liquid chromatography-mass spectrometry (LC/MS) at Fundación MEDINA in Spain as described by (González-Menéndez et al. 2016). The LC analysis was performed on an Agilent 1200 Rapid Resolution HPLC interfaced to a Bruker maXis mass spectrometer. The volume of sample injected was $2 \mu \mathrm{L}$. A Zorbax SB-C8 column $(2.1 \times 30 \mathrm{~mm}, 3.5 \mu \mathrm{m}$ particle size) was used for separation during which the column was maintained at $40{ }^{\circ} \mathrm{C}$ with a flow rate of $300 \mu \mathrm{L} \mathrm{min}{ }^{-1}$. Two solvents were used as the mobile phase. Solvent A consisted of 10\% acetonitrile and $90 \%$ water and solvent B consisted of $90 \%$ acetonitrile and $10 \%$ water. Both had $13 \mathrm{mM}$ ammonium formate and $0.01 \%(\mathrm{v} / \mathrm{v})$ trifluoroacetic acid. The gradient started at $10 \%$ B rose to $100 \%$ B in 6 min, was maintained at $100 \%$ B for $2 \mathrm{~min}$ and returned to $10 \% \mathrm{~B}$ for $2 \mathrm{~min}$ to initialize the system. Full diode array UV scans from 100 to $900 \mathrm{~nm}$ were collected in $4-\mathrm{nm}$ steps at $0.25 \mathrm{~s} \mathrm{scan}^{-1}$. Mass spectrometry acquisition to generate raw data was performed on an Agilent MSD 1100 mass spectrometer. Ionization was achieved by electrospray ionization (ESI) in positive mode. The instrumental parameters were: $4 \mathrm{kV}$ capillary voltage, drying gas flow of $11 \mathrm{~L} \mathrm{~min}^{-1}$ at $200{ }^{\circ} \mathrm{C}$ and nebulizer pressure at 2.8 bars. TFA-Na cluster ions were used for mass calibration of the instrument prior to sample injection. Each sample run was recalibrated by infusion with the same TFA-NA calibrant before the chromatographic front. Database matching was performed using an in-house developed application within which the UV signal, retention time, mass signal and molecular formula of the selected ions were compared to the UV-HPLC-HRMS data of known metabolites stored in the Fundación MEDINA database (High Resolution MS 647 of Actinobacteria, 384 of Fungi and 42 of Plants) and matching molecular formulas in the Chapman and Hall Dictionary of Natural Products database (290,000 entries of natural products) (Running 1993).

\section{Results}

Isolation of halophilic microorganisms from Zipaquirá salt mine and phylogenic diversity of isolated bacteria

In order to isolate halophilic microorganisms, we collected water, sediment, brine and solid (rock salt) samples from six sites in a salt mine in Zipaquirá, Colombia. This environment developed as a salt dome around 250 million years ago and then was raised above sea level during the late Tertiary period when the Andes Mountains were formed (de Cardale-Schrimpff 1978). The sampling sites had varying temperatures $\left(14-20^{\circ} \mathrm{C}\right)$ and $\mathrm{pH}(5.5-$ 6.5) and exhibited high chloride, sodium, calcium, sulfate and potassium levels (Additional file 1: Table S2). The recovered strains (135) were isolated from these hypersaline environments using several culture media and salinity conditions as described in the methodology section. Sequence analysis of the 16S rRNA (800-1400 bp) gene showed that most strains belonged to the Actinobacteria, Bacteroidetes, Firmicutes and Proteobacteria phyla, and only four Archaean strains were obtained, belonging to the genera Haloferax in phylum Euryarchaeota (Fig. 1).

The most abundant phylum was Firmicutes, represented by the Bacillaceae, Carnobacillaceae, Planococcaceae and Staphylococcaceae families. Bacillus was the most abundant genus (55 isolates), followed by Salimicrobium (4 isolates) and Marinococcus (3 isolates). The Proteobacteria phylum was represented by Gammaproteobacteria and Alphaproteobacteria classes, which are commonly found in halophilic environments (Chen et al. 2010). Within Gammaproteobacteria we isolated 


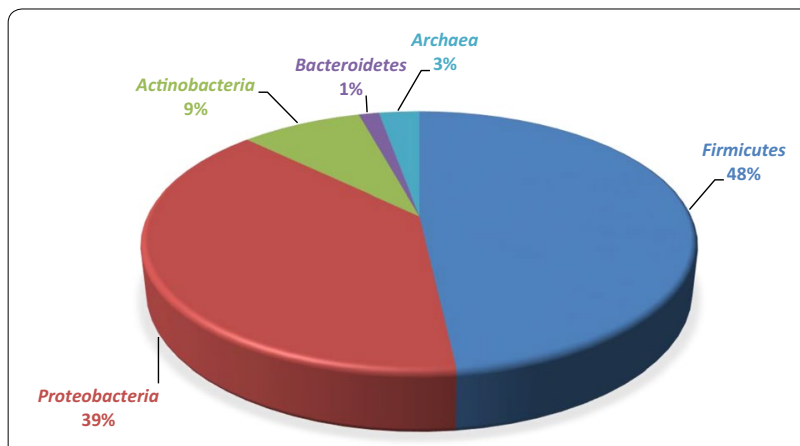

Fig. 1 Distribution of the relative abundance of the Bacteria and Archaea strains isolated at Zipaquirá salt mine

organisms from the Oceanospirillales order, in which the Halomonadaceae family was the most abundant, with a predominance of Chromohalobacter (26 isolates) and Halomonas genera (16 isolates). The Alteromonadales (Idiomarinaceae and Alteromonadaceae families) and Salinisphaerales orders (Salinisphaeraceae family) were also found. Within the Alphaproteobacteria, the organisms were distributed between Rhodobacterales (Rhodobacteraceae family) and Rhizobiales (Aurantimonadaceae family). Actinobacteria were represented by microorganisms of Janibacter, Isoptericola, Nesterenkonia, Ornithinimicrobium and Marmoricola genera. Bacteroidetes was represented by Salegentibacter genus (Fig. 2).

\section{Cytotoxic activity of halophilic isolates \\ Cytotoxic activity of crude extracts}

Cytotoxic activity was analyzed for 46 strains randomly selected, looking for including representatives of all genera from the samples collected at Zipaquirá and for 4 strains previously isolated from other saline environments. Ninety-five crude extracts were obtained, 50 of these by partition with chloroform, and 45 by partition with ethyl acetate. Seventeen extracts were not evaluated for their cytotoxic activity because of the yield of the recovered extract (less than $1 \mathrm{mg}$ ).

Six Actinobacteria strains were evaluated, Janibacter cremeus CG 12, Isoptericola spp. CG 20 and CG 23, Ornithinimicrobium kibberense CG 24, CG 28 and Nesterenkonia sandarakina CG 35. Strains CG 23, CG 24, and CG 12 showed high levels of cytotoxic activity $\left(\mathrm{IC}_{50}<60 \mu \mathrm{g} \mathrm{mL}-1\right)$ against the MCF-7 cell line under at least one of the growth conditions evaluated. In contrast, levels of activity against the $4 \mathrm{~T} 1$ cell line were low $\left(\mathrm{IC}_{50} \sim 110 \mu \mathrm{g} \mathrm{mL}^{-1}\right)$ and were only detected in chloroform extracts from the CG 24 and CG 35 strains. Interestingly, the biological activity of strains of the same species was found to vary. For instance, CG 28 and CG
35 strains, which were both identified as Nesterenkonia sandarakina, showed variation in activity when grown under the same experimental conditions (Table 1), suggesting that they are not redundant isolates.

Ten out of the 42 extracts obtained from 23 Firmicutes strains belonging to Alkalibacterium, Bacillus and Salimicrobium genera were shown to be cytotoxic against the MCF-7 cell line, with $\mathrm{IC}_{50}$ values ranging from 9 to $76 \mu \mathrm{g} \mathrm{mL}^{-1}$. In addition, five extracts showed cytotoxic activity against the $4 \mathrm{~T} 1$ cell line, with $\mathrm{IC}_{50}$ values of under $60 \mu \mathrm{g} \mathrm{mL}^{-1}$. One of the extracts obtained from Bacillus weihenstephanensis strain CG 31 presented selective cytotoxicity against the $4 \mathrm{~T} 1$ cell line, with an $\mathrm{IC}_{50}$ of $25.4 \mu \mathrm{g} \mathrm{mL}^{-1}$. No activity was detected in the extracts obtained from the three Salimicrobium strains evaluated (CG 74, 86 and 88). As observed with organisms of Actinobacteria, the results are strain specific and depend on the growth condition (Table 1).

We evaluated strains of the Gamma and Alphaproteobacteria classes. Within Gammaproteobacteria, 31 extracts obtained from 16 Halomonas, Chromohalobacter, Marinobacter and Shewanella strains were analyzed. Shewanella chilikensis strain USBA 344 showed the most cytotoxic activity of any of the extracts obtained in both chloroform and ethyl acetate against both cell lines with an $\mathrm{IC}_{50}<15 \mu \mathrm{g} \mathrm{mL}^{-1}$ against the $4 \mathrm{~T} 1$ cell line, and an $\mathrm{IC}_{50}<68 \mu \mathrm{g} \mathrm{mL}^{-1}$ against the MCF-7 cell line. In addition, high levels of cytotoxic activity were detected in the crude extract recovered in chloroform from Halomonas ventosae strain USBA 856, which presented an $\mathrm{IC}_{50}$ of $4.3 \mu \mathrm{g} \mathrm{mL}^{-1}$. From the six Chromohalobacter strains, only the extract obtained from Chromohalobacter canadensis CG 55 presented an $\mathrm{IC}_{50}<100 \mu \mathrm{g} \mathrm{mL} \mathrm{m}^{-1}$ against the $4 \mathrm{~T} 1$ cell line (Table 1).

Extracts of three out of the five strains from the Alphaproteobacteria class (Oceanibaculum, Caenispirillum, Labrenzia) showed cytotoxic activity $\left(\mathrm{IC}_{50}<100 \mu \mathrm{g} \mathrm{mL}^{-1}\right)$ against one or both cell lines, with the exception of extracts from Martellela mediterranea USBA 857 and Salipiger nanhaiensis CG 82 that were not active. In particular, two extracts stood out as having strong activity. One of these was the chloroform extract of Oceanibaculum indicum strain USBA 36, with an $\mathrm{IC}_{50}$ of $9 \mu \mathrm{g} \mathrm{mL}-1$ against the MCF-7 cell line, and the other was the chloroform extract of Labrenzia aggregata strain USBA 371 , with $\mathrm{IC}_{50}$ values $<5.5 \mu \mathrm{g} \mathrm{mL} \mathrm{L}^{-1}$ against both cell lines (Table 1).

These results indicate that several strains belonging to diverse bacterial phyla of the halophilic strains recovered in this study are interesting sources of cytotoxic extracts whose cytotoxic compounds are also of interest. The results above allowed selection of CG 12, CG 24, CG 22, CG 31, CG 33, CG 35, CG 50, CG 55, CG 63, CG 76, 


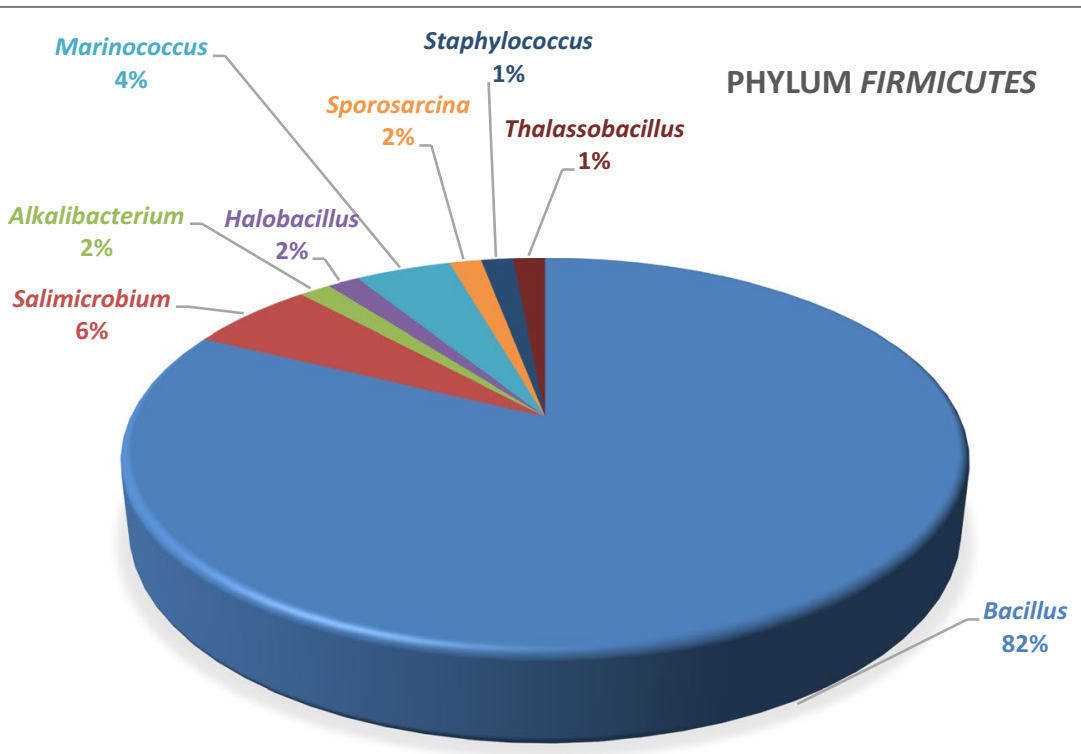

PHYLUM PROTEOBACTERIA

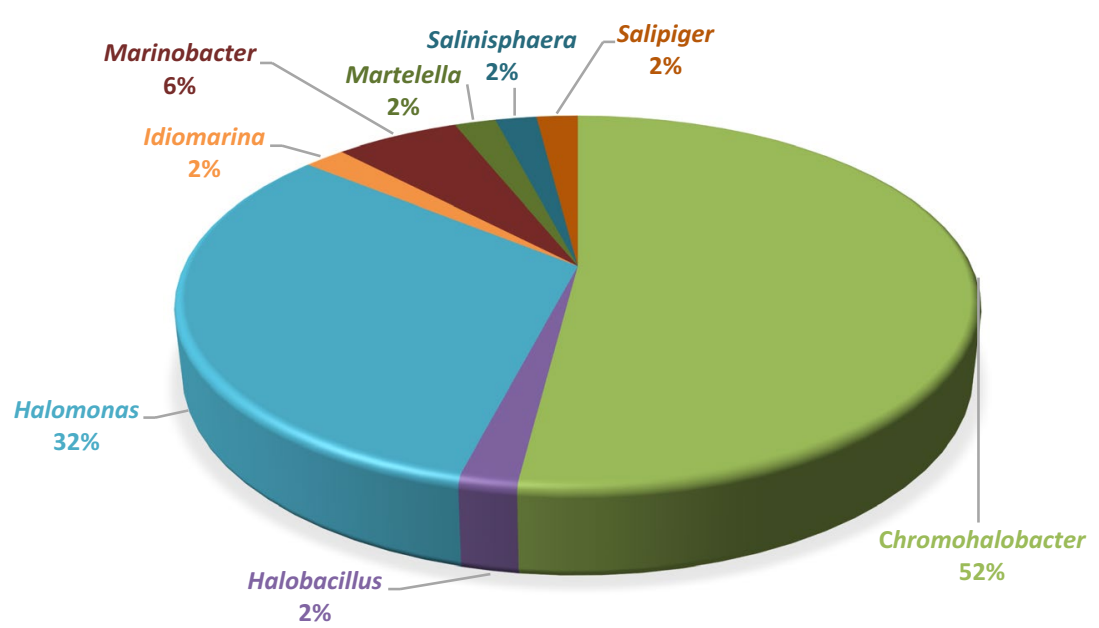

PHYLA ACTINOBACTERIA AND BACTEROIDETES

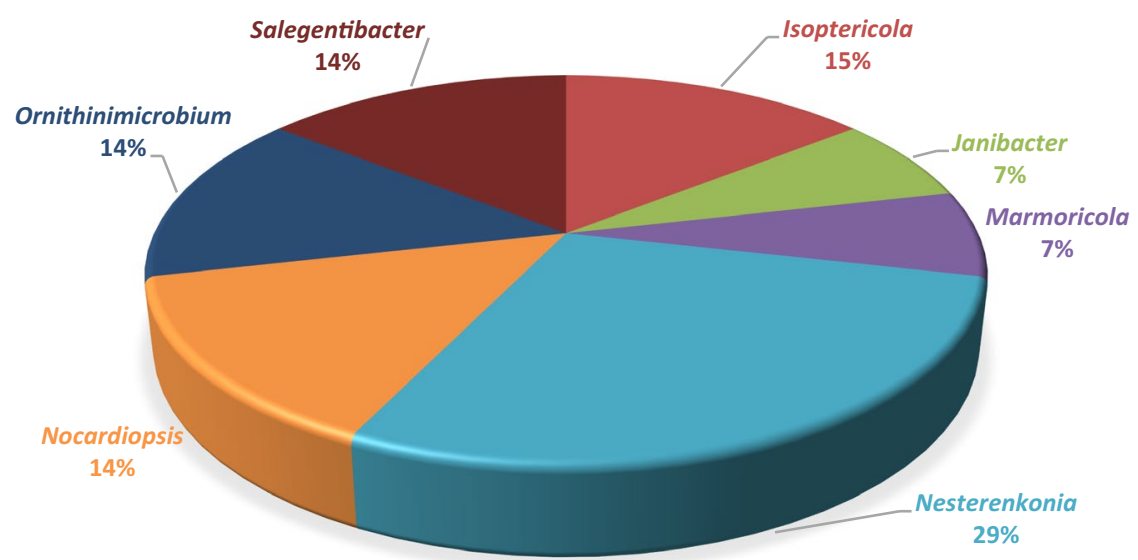

Fig. 2 Distribution of the relative abundance of the bacteria genera isolated at Zipaquirá salt mine 
Table 1 Cytotoxic activities of evaluated strains

\begin{tabular}{|c|c|c|c|c|c|}
\hline \multirow[t]{3}{*}{ Strain ID } & \multirow[t]{3}{*}{ Closed type strain (Accession No) (\% similarity) } & \multirow[t]{3}{*}{ Culture medium } & \multirow[t]{3}{*}{ Extraction solvent } & \multirow{2}{*}{\multicolumn{2}{|c|}{$\begin{array}{l}\text { Cytotoxic activity } \\
\text { of crude extracts } \\
\mathrm{IC}_{50}\left(\mu \mathrm{g} \mathrm{mL}^{-1}\right) \\
\text { Cellular line }\end{array}$}} \\
\hline & & & & & \\
\hline & & & & $4 \mathrm{~T} 1$ & MCF7 \\
\hline \multicolumn{6}{|c|}{ Actinobacteria } \\
\hline \multirow[t]{4}{*}{ CG 23} & Isoptericola halotolerans (KR476431.1) (98) & TSB $8 \%(w / v) ~ N a C l$ & Chloroform & $>250$ & 146.0 \\
\hline & & TSB $8 \%(w / v) ~ N a C l$ & Ethyl acetate & $>250$ & 53.9 \\
\hline & & TSB & Chloroform & - & - \\
\hline & & TSB & Ethyl acetate & - & - \\
\hline \multirow[t]{3}{*}{ CG 24} & Ornithinimicrobium kibberense (KM406766.1) (99) & TSB $8 \%(w / v) ~ N a C l$ & Chloroform & 106.0 & $>250$ \\
\hline & & TSB & Chloroform & - & - \\
\hline & & TSB & Ethyl acetate & $>250$ & 57.2 \\
\hline \multirow[t]{2}{*}{ CG 12} & Janibacter cremeus (KY775504.1) (94) & TSB $8 \%(w / v) ~ N a C l$ & Chloroform & 226 & 34.2 \\
\hline & & TSB $8 \%(w / v) ~ N a C l$ & Ethyl acetate & $>250$ & $>250$ \\
\hline \multirow[t]{2}{*}{ CG 35} & Nesterenkonia sandarakina (KF924226) (99) & TSB $8 \%(w / v) ~ N a C l$ & Chloroform & 117.8 & 188.6 \\
\hline & & TSB $8 \%(w / v) ~ N a C l$ & Ethyl acetate & $>250$ & $>250$ \\
\hline \multirow[t]{2}{*}{ CG 28} & Nesterenkonia sandarakina (KF924226) (98) & TSB $8 \%(w / v) ~ N a C l$ & Chloroform & - & - \\
\hline & & TSB $8 \%(w / v) ~ N a C l$ & Ethyl acetate & - & - \\
\hline \multirow[t]{3}{*}{ CG 20} & Isoptericola halotolerans (KP972642.1) (99) & TSB $8 \%(w / v) ~ N a C l$ & Chloroform & - & - \\
\hline & & TSB $8 \%(w / v) ~ N a C l$ & Ethyl acetate & - & - \\
\hline & & TSB & Chloroform & - & - \\
\hline \multicolumn{6}{|l|}{ Firmicutes } \\
\hline \multirow[t]{3}{*}{ CG 6} & Alkalibacterium putridalgicola (AB681988.1) (99) & Marine broth & Chloroform & 134.3 & 59.9 \\
\hline & & TSB & Chloroform & - & - \\
\hline & & TSB & Ethyl acetate & $>250$ & 118.8 \\
\hline \multirow[t]{2}{*}{ CG 3} & Bacillus aquimaris (KC335217.1) (99) & TSB & Chloroform & - & - \\
\hline & & TSB & Ethyl acetate & $>250$ & 87.3 \\
\hline USBA 882 & Bacillus aquimaris (NR_025241.1) (96) & Modified marine broth & Ethyl acetate & 192.0 & NT \\
\hline \multirow[t]{2}{*}{ USBA 899} & Bacillus hemicentroti (NR_025264.1) (97) & TSB 3\% (w/v) NaCl & Chloroform & - & - \\
\hline & & TSB 3\% (w/v) NaCl & Ethyl acetate & - & - \\
\hline \multirow[t]{2}{*}{ CG 13} & Bacillus aquimaris (KC335217.1) (92) & TSB 80 & Chloroform & - & - \\
\hline & & TSB 80 & Ethyl acetate & $>250$ & 200.5 \\
\hline \multirow[t]{2}{*}{ CG 25} & Bacillus hwajinpoensis (KR045741.1) (97) & TSB 80 & Chloroform & - & - \\
\hline & & TSB 80 & Ethyl acetate & $>250$ & 56.1 \\
\hline CG 36 & Bacillus aerophilus (KR010180.1) (99) & TSB & Chloroform & 173.2 & 8.8 \\
\hline \multirow[t]{2}{*}{ CG 42} & Bacillus hwajinpoensis (KX817927.1) (99) & TSB 3\% (w/v) NaCl & Chloroform & - & - \\
\hline & & TSB & Chloroform & - & - \\
\hline CG 69 & Bacillus aerophilus (KU236478.1) (99) & TSB & Chloroform & $>250$ & 224.0 \\
\hline \multirow[t]{2}{*}{ CG 11} & Bacillus altitudinis (NR_118439.1) (99) & TSB & Chloroform & - & - \\
\hline & & TSB & Ethyl acetate & $>250$ & $>250$ \\
\hline \multirow[t]{2}{*}{ CG 7} & Bacillus aquimaris (NR_113995.1) (95) & TSB & Chloroform & - & - \\
\hline & & TSB & Ethyl acetate & $>250$ & $>250$ \\
\hline \multirow[t]{2}{*}{ CG 69} & Bacillus aerophilus (KU236478.1) (99) & TSB 3\% (w/v) NaCl & Chloroform & - & - \\
\hline & & TSB 3\% (w/v) NaCl & Ethyl acetate & - & - \\
\hline \multirow[t]{4}{*}{ CG 15} & Bacillus licheniformis (S002290488) (98) & TSB & Chloroform & $>250$ & 136 \\
\hline & & TSB & Ethyl acetate & $>250$ & 42.0 \\
\hline & & Marine broth & Chloroform & - & - \\
\hline & & Marine broth & Ethyl acetate & $>250$ & 65.6 \\
\hline
\end{tabular}


Table 1 continued

\begin{tabular}{|c|c|c|c|c|c|}
\hline \multirow[t]{3}{*}{ Strain ID } & \multirow[t]{3}{*}{ Closed type strain (Accession No) (\% similarity) } & \multirow[t]{3}{*}{ Culture medium } & \multirow[t]{3}{*}{ Extraction solvent } & \multirow{2}{*}{\multicolumn{2}{|c|}{$\begin{array}{l}\text { Cytotoxic activity } \\
\text { of crude extracts } \\
\mathrm{IC}_{50}\left(\mu \mathrm{g} \mathrm{mL}^{-1}\right) \\
\text { Cellular line }\end{array}$}} \\
\hline & & & & & \\
\hline & & & & $4 \mathrm{T1}$ & MCF7 \\
\hline \multirow[t]{2}{*}{ USBA 866} & Bacillus vietnamensis (NR_025264.1) (97) & Modified marine broth & Chloroform & $>250$ & 185.7 \\
\hline & & Modified marine broth & Ethyl acetate & 48.3 & 65.7 \\
\hline USBA 867 & Bacillus simplex (NR_109010.1) (98) & Modified marine broth & Ethyl acetate & $>250$ & 134.8 \\
\hline USBA 868 & Bacillus hemicentroti (NR_114919.1) (99) & Modified marine broth & Ethyl acetate & 56.2 & 76.2 \\
\hline \multirow[t]{2}{*}{ CG 22} & Bacillus subtilis (CP021499.1) (100) & TSB & Chloroform & 29.8 & 76.5 \\
\hline & & TSB & Ethyl acetate & 21.7 & 75.5 \\
\hline CG 63 & Bacillus amyloliquefaciens (KY784657.1) (99) & TSB 80 & Chloroform & 107 & 76.4 \\
\hline CG 31 & Bacillus weihenstephanensis (HF678914.2) (99) & TSB 8\% (w/v) $\mathrm{NaCl}$ & Ethyl acetate & 25.4 & 144.4 \\
\hline \multirow[t]{2}{*}{ CG 57} & Bacillus weihenstephanensis (KY120752.1) (100) & TSB & Chloroform & - & - \\
\hline & & TSB & Ethyl acetate & - & - \\
\hline \multirow[t]{2}{*}{ CG 74} & Salimicrobium flavidum (EU868860.1) (96) & TSB 8\% (w/v) $\mathrm{NaCl}$ & Chloroform & - & - \\
\hline & & TSB 8\% (w/v) $\mathrm{NaCl}$ & Ethyl acetate & - & - \\
\hline \multirow[t]{2}{*}{ CG 86} & Salimicrobium flavidum (EU868860.1) (96) & TSB 8\% (w/v) $\mathrm{NaCl}$ & Chloroform & - & - \\
\hline & & TSB $8 \%(w / v) ~ N a C l$ & Ethyl acetate & - & - \\
\hline \multirow[t]{2}{*}{ CG 88} & Salimicrobium flavidum (EU868860.1) (97) & TSB 8\% (w/v) $\mathrm{NaCl}$ & Chloroform & - & - \\
\hline & & 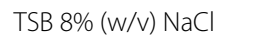 & Ethyl acetate & - & - \\
\hline \multicolumn{6}{|c|}{ Gammaproteobacteria } \\
\hline CG 76 & Halomonas alkaliantarctica (NR_145910.1) (91) & TSB 4\% (w/v) $\mathrm{NaCl}$ & Ethyl acetate & $>250$ & 96.7 \\
\hline CGX & Halomonas alkaliantarctica (NR_145910.1) (91) & TSB $8 \%(w / v) ~ N a C l$ & Chloroform & 82.3 & 101.3 \\
\hline \multirow[t]{2}{*}{ CG 60} & Halomonas ventosae (NR_044519.1) (93) & TSB 8\% (w/v) $\mathrm{NaCl}$ & Chloroform & - & - \\
\hline & & TSB $8 \%(w / v) ~ N a C l$ & Ethyl acetate & $>250$ & $>250$ \\
\hline \multirow[t]{2}{*}{ CG 83} & Halomonas ventosae (NR_044519.1) (99) & TSB 8\% (w/v) $\mathrm{NaCl}$ & Chloroform & - & - \\
\hline & & TSB $8 \%(w / v) ~ N a C l$ & Ethyl acetate & - & - \\
\hline \multirow[t]{3}{*}{ USBA 856} & Halomonas ventosae (NR_042812.1) (99) & Modified marine broth & Chloroform & 4.3 & 217.1 \\
\hline & & Modified marine broth & Ethyl acetate & - & - \\
\hline & & TSB & Ethyl acetate & - & - \\
\hline \multirow[t]{2}{*}{ CG 78} & Halomonas janggokensis (AB042501.2) (92) & TSB 8\% (w/v) $\mathrm{NaCl}$ & Chloroform & - & - \\
\hline & & TSB $8 \%(w / v) ~ N a C l$ & Ethyl acetate & - & - \\
\hline \multirow[t]{2}{*}{ CG 66} & Halomonas fontilapidosi (KT984005.1) (99) & TSB 8\% (w/v) $\mathrm{NaCl}$ & Chloroform & - & - \\
\hline & & 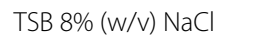 & Ethyl acetate & - & - \\
\hline \multirow[t]{2}{*}{ USBA 873} & Halomonas taeanensis (NR_043087.1) (96) & TSB 3\% (w/v) $\mathrm{NaCl}$ & Chloroform & - & - \\
\hline & & TSB 3\% (w/v) $\mathrm{NaCl}$ & Ethyl acetate & - & - \\
\hline \multirow[t]{2}{*}{ CG 50} & Chromohalobacterjaponicus (NR_040965) (97) & TSB 8\% (w/v) $\mathrm{NaCl}$ & Chloroform & 158.6 & 115 \\
\hline & & TSB 8\% (w/v) $\mathrm{NaCl}$ & Ethyl acetate & - & - \\
\hline \multirow[t]{2}{*}{ CG 72} & Chromohalobacter japonicus (NR_040965) (99) & 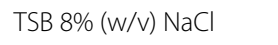 & Chloroform & - & - \\
\hline & & TSB 8\% (w/v) $\mathrm{NaCl}$ & Ethyl acetate & - & - \\
\hline \multirow[t]{2}{*}{ CG 55} & Chromohalobacter canadensis (NR_114545.1) (98) & TSB 8\% (w/v) $\mathrm{NaCl}$ & Chloroform & - & - \\
\hline & & TSB 8\% (w/v) $\mathrm{NaCl}$ & Ethyl acetate & 69.3 & 137.6 \\
\hline \multirow[t]{2}{*}{ USBA862 } & Chromohalobacter japonicus (NR_114545.1) (96) & TSB 3\% (w/v) NaCl & Chloroform & - & - \\
\hline & & TSB 3\% (w/v) $\mathrm{NaCl}$ & Ethyl acetate & - & - \\
\hline \multirow[t]{2}{*}{ USBA 861} & Chromohalobacter japonicus (NR_114545.1) (95) & TSB 3\% (w/v) $\mathrm{NaCl}$ & Chloroform & - & - \\
\hline & & TSB 3\% (w/v) $\mathrm{NaCl}$ & Ethyl acetate & $>250$ & $>250$ \\
\hline USBA 896 & Chromohalobacter canadensis (NR_114545.1) (96) & TSB 3\% (w/v) $\mathrm{NaCl}$ & Chloroform & - & - \\
\hline & & TSB 3\% (w/v) $\mathrm{NaCl}$ & Ethyl acetate & - & - \\
\hline
\end{tabular}


Table 1 continued

\begin{tabular}{|c|c|c|c|c|c|}
\hline \multirow[t]{3}{*}{ Strain ID } & \multirow[t]{3}{*}{ Closed type strain (Accession No) (\% similarity) } & \multirow[t]{3}{*}{ Culture medium } & \multirow[t]{3}{*}{ Extraction solvent } & \multirow{2}{*}{\multicolumn{2}{|c|}{$\begin{array}{l}\text { Cytotoxic activity } \\
\text { of crude extracts } \\
\mathrm{IC}_{50}\left(\mu \mathrm{g} \mathrm{mL}^{-1}\right) \\
\text { Cellular line }\end{array}$}} \\
\hline & & & & & \\
\hline & & & & $4 \mathrm{~T} 1$ & MCF7 \\
\hline \multirow[t]{2}{*}{ USBA 344} & Shawanella chilikensis (BALO01000089) (99) & TSB 3\% (w/v) NaCl & Chloroform & 5.3 & 67.9 \\
\hline & & TSB 3\% (w/v) NaCl & Ethyl acetate & 15.3 & 21.8 \\
\hline \multirow[t]{2}{*}{ CG 65} & Marinobacter persicus (NR_109110.1) (98) & TSB 8\% (w/v) NaCl & Chloroform & - & - \\
\hline & & TSB 8\% (w/v) NaCl & Ethyl acetate & - & - \\
\hline \multicolumn{6}{|c|}{ Alphaproteobacteria } \\
\hline CG 82 & Salipiger nanhaiensis (NR_134804.1) (98) & TSB & Ethyl acetate & $>250$ & $>250$ \\
\hline USBA 36 & Oceanibaculum indicum (NR_044547.1) (99) & TSB 5\% (w/v) NaCl & Chloroform & 173.2 & 8.8 \\
\hline \multirow[t]{2}{*}{ USBA 85} & Caenispirillum bisanense (NR_04408.1) (98) & TSB & Chloroform & 69.6 & 90.5 \\
\hline & & TSB & Ethyl acetate & 29.5 & 74.1 \\
\hline USBA 857 & Martelella mediterránea (NR_043068.1) (98) & Marine broth & Chloroform & $>250$ & $>250$ \\
\hline USBA 371 & Labrenzia aggregata (NR_11386.1) (99) & TSB 3\% (w/v) NaCl & Chloroform & 5.5 & 4.5 \\
\hline
\end{tabular}

USBA 344, USBA 85 and USBA 371 strains as the most promising sources of cytotoxic compounds. Differences in the cytotoxicity of one strain at different salt concentrations during culturing on the growth media will be explored in further studies. In addition, isolates identified as taxonomically identical showed different $\mathrm{IC}_{50}$ values, suggesting differential production of bioactive metabolites.

\section{LC/MS analysis of active extracts and fractions}

A solid-phase extraction (SPE) fractionation and LC/MS analysis strategy was used to identify compounds present in the extracts of the 13 strains selected. SPE was performed using Diol-SPE cartridges and eluting with solvents of increasing polarity as described in the methods section. Cytotoxicity of the fractions obtained was evaluated, and those active fractions were then analyzed by LC/MS (Table 2, Fig. 3).

In some cases, fractionation of the crude extract increased cytotoxic activity against both cell lines. This was the case for the crude extract of Nesterenkonia sandarakina CG 35 obtained with chloroform which had an $\mathrm{IC}_{50}$ of $\geq 118 \mu \mathrm{g} \mathrm{mL} \mathrm{m}^{-1}$, while an $\mathrm{IC}_{50}$ of less than $88 \mu \mathrm{g} \mathrm{mL}^{-1}$ was detected in the non polar F2.1 and F2.2 (hexane/ethyl acetate $8: 2$ ) and medium polarity F5.2 (ethyl acetate/ethanol 9:1) fractions (Fig. 3a).

The LC/MS analysis of the crude extract of $N$. sandarakina CG 35 and dereplication using the Chapman and Hall Dictionary of Natural Products database (Running 1993) and the Fundación Medina data base, allowed identification of 1 -acetyl- $\beta$-carboline 1, the diketopiperazines (DKPs) cyclo(2-OHPro-Phe) 2, cyclo(Pro-Phe) 3, brevianamide F 4, cyclo(Leu-Phe)5, cyclo(Val-Phe)
6, cyclo(Phe-Phe) 7, cyclo(Leu-Pro) 8 (Fig. 4a), and one compound with $m / z 286.1542$ not found in the DNP data base. The LC/MS analysis of the F2.2 fraction, which had the highest cytotoxic activity against both cell lines, also showed the presence of 1 -acetyl- $\beta$-carboline 1 . The DKPs detected in the crude extract were again obtained from the more polar fractions (F4.1, F5.1 and F5.2) and the presence of two possible new natural compounds was detected in the F2.2 fraction with $\mathrm{m} / \mathrm{z}$ of 211.0869 and 552.2438 .

In other cases, fractionation resulted in decreases in cytotoxic activity. The crude extract obtained from J. cremeus strain CG 12 had an $\mathrm{IC}_{50}$ of $226 \mu \mathrm{g} \mathrm{mL}{ }^{-1}$ against $4 \mathrm{~T} 1$ and $34 \mu \mathrm{g} \mathrm{mL}{ }^{-1}$ against MCF-7, but upon fractionation activity against the MCF-7 cell line was lost, and activity against the $4 \mathrm{~T} 1$ cell line was reduced. Only slight activity was observed in the non-polar fractions (F2.2 and F3.2) (data not shown). The decreases in the activity could be related to synergistic effects or analytical procedures that should be optimized in order to increase the recovery of the compounds present in the extracts.

For O. kibberense strain $\mathrm{CG} 24$, the $\mathrm{IC}_{50}$ decreased after fractionation from 57 to $185 \mu \mathrm{g} \mathrm{mL} \mathrm{m}^{-1}$ against the MCF-7 cell line, the latter in the F6.2 polar fraction (Table 2, Fig. 3b). LC-MS analysis of the crude extract and the F6.2 fraction revealed the presence of the DKPs cyclo(2OHPro-Phe) 2, cyclo(Trp-Tyr) 9 (Fig. 4b), and ions of compounds that did not match the databases here used at $m / z 235.1189$. The clearest difference was the presence of the compound lagunamycin 10 (Fig. 4b) in the crude extract, which was not detected from the active fraction.

Fractionation of extracts from Bacillus strains (CG 22, CG 63, CG 31 and CG 33) also gave variable results. 
Table 2 Cytotoxic activities of fractions from the crude extracts

\begin{tabular}{|c|c|c|c|c|}
\hline \multirow[t]{3}{*}{ Strain ID } & \multirow[t]{3}{*}{$\begin{array}{l}\text { Crude extract/frac- } \\
\text { tion }\end{array}$} & \multirow[t]{3}{*}{ Extraction solvent } & \multirow{2}{*}{\multicolumn{2}{|c|}{$\begin{array}{l}\text { Cytotoxic } \\
\text { activity } \\
\text { of frac- } \\
\text { tions } \mathrm{IC}_{50} \\
\left(\mu \mathrm{gL}^{-1}\right) \\
\text { Cellular line }\end{array}$}} \\
\hline & & & & \\
\hline & & & $4 \mathrm{~T} 1$ & MCF7 \\
\hline \multirow[t]{6}{*}{ CG 35} & Crude extract & Chloroform & 117.8 & 188.6 \\
\hline & $F 2.1$ & $\begin{array}{l}\text { Hexane:ethyl acetate } \\
8: 2\end{array}$ & 73.8 & 87.9 \\
\hline & $F 2.2$ & $\begin{array}{l}\text { Hexane:ethyl acetate } \\
8: 2\end{array}$ & 69.6 & 68.4 \\
\hline & F 4.1 & Ethyl acetate & 88.2 & 247.2 \\
\hline & F 5.2 & $\begin{array}{l}\text { Ethyl } \\
\text { acetate:methanol } \\
9: 1\end{array}$ & 84.5 & 79.7 \\
\hline & F 5.3 & $\begin{array}{l}\text { Ethyl } \\
\text { acetate:methanol } \\
9: 1\end{array}$ & 72.6 & 96.3 \\
\hline \multirow[t]{2}{*}{ CG 24} & Crude extract & Ethyl acetate & $>250$ & 57.2 \\
\hline & F 6.2 & Methanol & $>250$ & 138.6 \\
\hline \multirow[t]{2}{*}{ CG 22} & Crude extract & Chloroform & 29.8 & 76.5 \\
\hline & F 6.1 & Methanol & $>250$ & 44.8 \\
\hline \multirow[t]{2}{*}{ CG 63} & Crude extract & Chloroform & 107 & 76.4 \\
\hline & F 4.1 & Ethyl acetate & ND & 44.4 \\
\hline \multirow[t]{2}{*}{ CG 50} & Crude extract & Chloroform & 158.6 & 115 \\
\hline & F 6.1 & Methanol & 31.2 & $>250$ \\
\hline \multirow[t]{2}{*}{ USBA 344} & Crude extract & Ethyl acetate & 15 & 22 \\
\hline & $F 3.2$ & $\begin{array}{l}\text { Hexane:ethyl acetate } \\
1: 1\end{array}$ & 229.2 & 80.3 \\
\hline \multirow[t]{5}{*}{ USBA 371} & Crude extract & Chloroform & 5.5 & 4.5 \\
\hline & F 4.1 & Ethyl acetate & 15.2 & 26.6 \\
\hline & F 4.2 & $\begin{array}{l}\text { Ethyl } \\
\text { acetate:methanol } \\
9: 1\end{array}$ & 8.9 & 16.3 \\
\hline & F 5.1 & $\begin{array}{l}\text { Ethyl } \\
\text { acetate:methanol } \\
9: 1\end{array}$ & 7.2 & 14.5 \\
\hline & F 6.1 & Methanol & 28.7 & 49.0 \\
\hline
\end{tabular}

ND No data

While the crude extract of strain CG 22 had cytotoxic activity against both cell lines, only the most polar fraction (F6.1) was active against the MCF-7 cell line ( $\mathrm{IC}_{50}$ of $45 \mu \mathrm{g} \mathrm{mL}{ }^{-1}$ ) (Table 2, Fig. 3c). This fraction contained DKPs cyclo(His-Pro) 11 (Fig. 4c), cyclo(Pro-Phe) 3, as well as ions for analogs of surfactins such as surfactin A1, 4-L-alaninesurfactin $C$, surfactin $B 1$ and surfactin A 12 (Fig. 4c), and an unidentified compound with $m / z=3416.5966 \mathrm{Da}$. In the case of strain CG 63, fractionation of the crude extract, which had activity against both cell lines, indicated that only the medium polarity fraction (F4.1) had cytotoxic activity against MCF-7 ( $\mathrm{IC}_{50}$ value of $44.4 \mu \mathrm{g} \mathrm{mL}^{-1}$ ) (Table 2, Fig. 3d). In this fraction, cyclo(Pro-Phe) 3, cyclo(Pro-Val) 13, and several stereoisomers of macrolactin 14, and succinoylmacrolactin 15, surfactins and iturin 16, were detected (Fig. 4d). Since cytotoxic activity was lost in fractions from the extracts of strains CG 31 and CG $33\left(\mathrm{IC}_{50}>250 \mu \mathrm{g} \mathrm{mL}{ }^{-1}\right)$, these were not analyzed by LC-MS.

Fractionation of extracts from Chromohalobacter increased their activity in the case of CG 50 for which the most polar fraction (F6.1) showed an $\mathrm{IC}_{50}=31.2 \mu \mathrm{g} \mathrm{mL}^{-1}$ against the $4 \mathrm{~T} 1$ cell line (Table 2). LC/MS analysis of this fraction again showed the presence of the DKPs cyclo(Pro-Ala) 17, cyclo(Pro-Thr) 18, cyclo(Ala-Phe) 19, cyclo(Pro-Tyr) 20 (Fig. 4e) and cyclo (Pro-Phe) 3. In contrast, activity strongly decreases upon fractionation of the extract from strain CG 55, so LC-MS analysis was not performed.

After fractionation of the crude extract of $H$. salicampi CG 76, the cytotoxicity analysis of the recovered fractions showed no activity against the MCF-7 cell line. The initial $\mathrm{IC}_{50}$ in the crude extract was $95 \mu \mathrm{g} \mathrm{mL} \mathrm{m}^{-1}$ against this cell line.

Although Shewanella chilikensis strain USBA 344 showed high levels of cytotoxic activity in the crude chloroform $\left(\mathrm{IC}_{50}\right.$ of $35 \mu \mathrm{g} \mathrm{mL} \mathrm{m}^{-1}$ against $4 \mathrm{~T} 1$ and $68 \mu \mathrm{g} \mathrm{mL}^{-1}$ against MCF-7) and ethyl acetate extracts $\left(\mathrm{IC}_{50} 15 \mu \mathrm{g} \mathrm{mL} \mathrm{m}^{-1}\right.$ against $4 \mathrm{~T} 1$ and $22 \mu \mathrm{g} \mathrm{mL}^{-1}$ against MCF-7), after fractionation of these extracts, test showed that cytotoxic activity against the $4 \mathrm{~T} 1$ cell line had been lost. Conversely, we detected activity from the non-polar fraction F3.2, with an $\mathrm{IC}_{50}$ of $80 \mu \mathrm{g} \cdot \mathrm{mL}^{-1}$ against the MCF-7 cell line (Table 2, Fig. 3e). Analysis of the ethyl acetate extract allowed identification of the presence of cyclo(Pro-Tyr) 9 and cyclo(Pro-His) 11, along with two unidentified compounds.

Fractionation of Labrenzia aggregata USBA 371, which showed the highest levels of cytotoxicity of all the strains evaluated $\left(\mathrm{IC}_{50}<5.5 \mu \mathrm{g} \mathrm{mL}{ }^{-1}\right)$, also resulted in fractions with high levels of activity against both cell lines. The medium polarity F4.1, F4.2 and F5.1 fractions presented $\mathrm{IC}_{50}$ values $<16 \mu \mathrm{g} \mathrm{mL}$ against the $4 \mathrm{~T} 1$ cell line and $<27 \mu \mathrm{g} \mathrm{mL}^{-1}$ against MCF-7, whereas the polar fraction F6.1 presented $\mathrm{IC}_{50}$ values $<29 \mu \mathrm{g} \mathrm{mL}^{-1}$ against $4 \mathrm{~T} 1$ and $<49 \mu \mathrm{g} \mathrm{mL}^{-1}$ against MCF-7 (Table 2, Fig. 3f). We detected DKPs cyclo(Pro-Phe) 3, cyclo(Leu-Phe) 5, cyclo(Val-Phe) 6, cyclo(Phe-Phe) 7, cyclo(Pro-Leu) 8, cyclo(His-Pro) 11, cyclo(Pro-Val) 13, cyclo(Pro-Ala) 17, and cyclo(ProTyr) 20. 


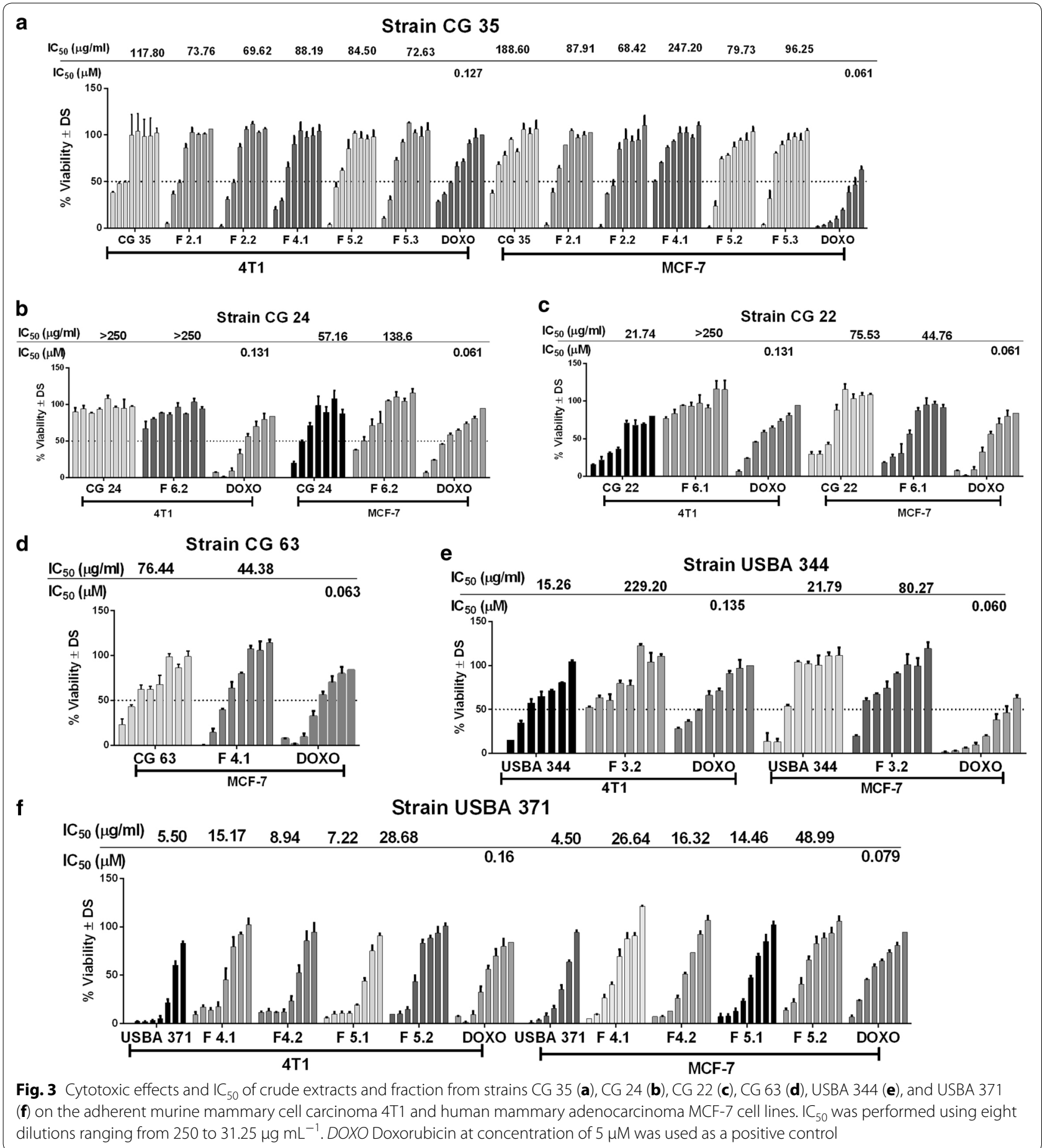

\section{Discussion}

Halophilic organisms that have evolved and adapted in oligotrophic marine and other saline environments may produce novel molecules with promising biological activity (Zhang 2005). In this study, we therefore analyzed cytotoxic activity against tumor cell lines of halophilic and halotolerant microorganisms isolated from a hypersaline environment. Most of the strains were isolated on halophilic medium and culture media made with saline water from sampling sites and supplemented with several 


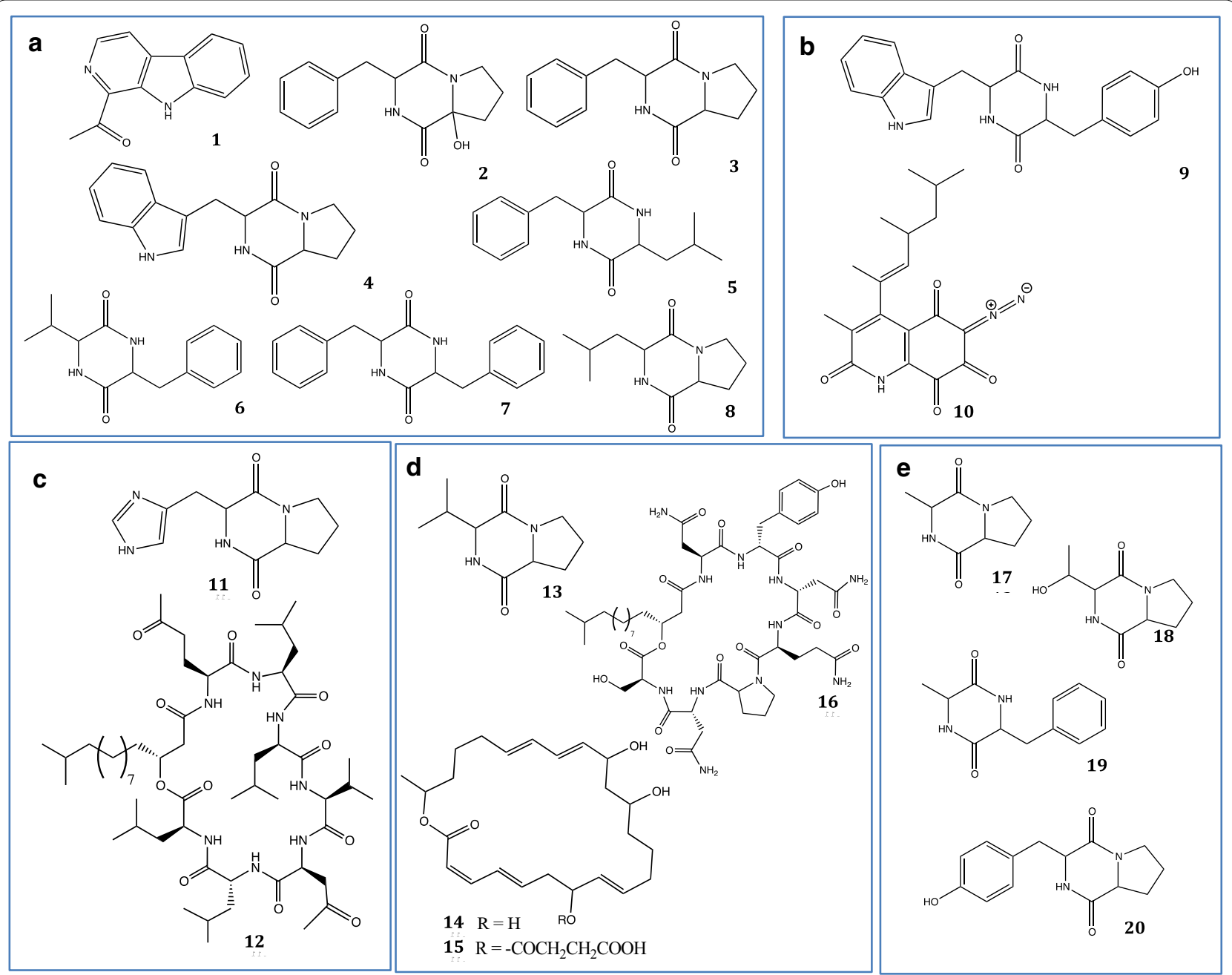

Fig. 4 Compounds identified by LC/MS from strains CG 35 (a), CG 24 (b), CG 22 (c), CG 63 (d), and CG 50 (e). a 1-acetyl- $\beta$-carboline 1, cyclo(2OHPro-Phe) 2, cyclo(Pro-Phe) 3, brevianamide F 4, cyclo(Leu-Phe) 5, cyclo(Val-Phe) 6, and cyclo(Phe-Phe) 7, cyclo(Pro-Leu) 8; b cyclo(Trp-Tyr), lagunamycin 10; c cyclo(His-Pro) 11; Surfactin 12; d cyclo(Pro-Val) 13, macrolactin 14, succinoylmacrolactin 15, and iturin 16; e cyclo(Pro-Ala) 17, cyclo(Pro-Thr) 18, cyclo(Ala-Phe) 19, cyclo(Pro-Tyr) 20

carbon sources. The largest number of isolates were obtained from samples from sampling sites P3 and P5.

Most of these isolates have been previously reported in marine or oceanic environments and other highly saline environments (Claverías et al. 2015; da Silva et al. 2015). Based on the conditions used for recovering these microorganisms, the majority of our isolates are heterotrophic, mesophilic, aerobic or facultative aerobes that are halophilic or halotolerant organisms that can cope with salt concentrations ranging from 0 to $8 \% \mathrm{NaCl}(\mathrm{w} / \mathrm{v})$. Several colonies had yellow, orange, pink and cream pigments, and most were brightened with a creamy texture and were completely round. The exceptions were some Bacillus strains whose colonies were opaque with irregular borders. The growth times of most isolates ranged between 24 and $72 \mathrm{~h}$, with some exceptions of up to 10 days for Actinomycetes.

A total of $43 \%$ of the strains isolated belonged to Bacillus. The species of this genus are ubiquitous in various environments and are known for having a large number of biosynthetic gene clusters for the production of secondary metabolites with cytotoxic or antimicrobial activities that promote plant growth or act as biocontrol agents (Ongena and Jacques 2008; Aleti et al. 2015). In this study, we isolated strains of ubiquitous species such as $B$. subtilis, B. amyloliquefaciens, B. pumilus and B. licheniformis, and species typically associated with marine habitats such as B. aquimaris, B. baekryungensis and B. hwajinpoensis. All of these marine strains have been reported in marine sponges with bioactive potential due to the presence of 
structurally unrelated antimicrobial compounds including polyketides, non-ribosomal synthesized peptides and bacteriocins (Phelan et al. 2012). In our study, we detected polyketides with high levels of cytotoxicity such as macrolactin from extracts of Bacillus amyloliquefaciens CG 63, and we detected non-ribosomally synthesized lipopeptides like surfactins and iturins from Bacillus amyloliquefaciens CG 63 and from Bacillus subtilis CG 22. The cytotoxic activity of macrolactin has been demonstrated previously (Kim et al. 2011; Regmi et al. 2015). Surfactins and iturins are well documented for their antitumor, antifungal, antibacterial, antiviral and insecticidal activities (Vollenbroich et al. 1997; Stein 2005; Kim et al. 2007, 2010; Dey et al. 2015).

Other genera with abundant representatives among our isolates were Chromohalobacter and Halomonas which have been reported to produce metabolites with antimicrobial and cytotoxic activity. In Halomonas, cytotoxic activity with an $\mathrm{IC}_{50}>100 \mu \mathrm{g} \mathrm{mL}{ }^{-1}$ has been reported in extracts obtained from $H$. ventosae and $H$. salina (Chen et al. 2010). Promising cytotoxic activity has also been reported in $H$. meridiana and $H$. aquamarina (Sagar et al. 2013). In this study, we detected cytotoxic activity in Halomonas alkaliantarctica strain CG 76, and H. ventosae strain USBA 856. This latter strain has been studied mainly for its ability to produce exopolysaccharides with physical and chemical properties that confer several bioactive functions (Mata et al. 2006). From the six strains of Chromohalobacter evaluated, strains CG 50 and CG 55 showed cytotoxic activity. Sagar et al. (2013) have also reported cytotoxic activity of Chromohalobacter strains against the MCF-7 and HeLa (cervical carcinoma) cell lines in lipophilic extracts obtained with chloroform. In this study, we obtained DKPs consisting mainly of proline in the chloroform extract. Similar results were reported by Bitzer et al. (2006) who detected DKPs with a predominance of this amino acid in lipophilic extracts obtained from Halomonas spp.

The genera Nesterenkonia, Isoptericola, Ornithinimicrobium and Janibacter are included within the rare Actinobacteria group and are less frequently isolated than Streptomyces (Claverías et al. 2015). They are an important focus of new generation pharmaceutical agents (Mahmoud and Kalendar 2016). The compounds detected in all fractions of these "rare" actinomycetes correspond mainly to DKPs. These compounds have also been previously reported in several marine actinomycetes, which have emerged as producers of novel DKPs. These include cyclomarazines (Schultz et al. 2008), naseseazines (Raju et al. 2009), nocazines D and E and methoxyneihumicin (Zhang et al. 2013). In addition to DKPs, we isolated 1-acetyl- $\beta$-carboline (Shin et al. 2010) from the F2.2 fraction of Nesterenkonia sp. strain CG 35. This fraction showed cytotoxic activity against both cell lines $\left(<70 \mu \mathrm{g} \mathrm{mL} \mathrm{m}^{-1}\right)$ although, 1 -acetyl- $\beta$-carboline has not been reported to be a cytotoxic compound. However, it has been shown to have herbicidal, fungicidal and antimicrobial activities, the latter against methicillin-resistant Staphylococcus aureus MRSA (Elleuch et al. 2010; Shin et al. 2010).

The strain with the highest levels of cytotoxic activity was Labrenzia aggregata USBA 371 which was isolated from the Salado de Consotá salt spring (Díaz-Cárdenas and Baena 2015). Organisms of the Labrenzia genus isolated from marine sponges have presented antimicrobial activity against $B$. subtilis and MRSA (Graça et al. 2013). However, no previous reports have identified a cytotoxic effect or have shown that this effect is related to the presence of a mixture of DKPs, as shown in this study. On the other hand, dereplication of the LC/MS data allowed identification of several compounds from the database here used as described below. However, many ions showed no coincidence in the database, which indicates the metabolic potential of the extracts analyzed. This potential will be further evaluated within our group.

Compounds isolated were mainly DKPs, although lipopeptides and polyketides were also isolated. The DKPs are produced by the condensation of two amino acids and are common metabolites of bacteria, fungi and sponges. These compounds can act as signal molecules (Tommonaro et al. 2012) and present antifungal (Nishanth Kumar et al. 2012), antibacterial (Fdhila et al. 2003) and antitumor activities (van der Merwe et al. 2008) due to their chiral and functionalized structure which allows them to bind with high affinity to a great variety of receptors. These compounds exhibit a wide range of biological activities (Martins and Carvalho 2007). Even though we have presented the dereplication of 20 compounds, the data obtained demonstrate enormous chemical diversity to be explored. Studies to this end are currently underway in our laboratories. These strains also represent a starting point for the development of biotechnological processes for obtaining these and other compounds for further studies and applications.

Despite the importance of bioactive compounds for the development of novel therapeutic substances, only a small fraction of microorganisms isolated in pure cultures has been evaluated for production of bioactive molecules. Most studies have focused on a few biological groups other than halophilic microorganisms. Although marine environments have been identified as a major source of drug candidates in clinical trials, and a search for sources of new chemical diversity in the oceans is ongoing, this study demonstrates that terrestrial hypersaline environments have great potential for becoming a major source of bioactive molecules. Our study shows a wide diversity of halophilic 
and halotolerant bacteria in hypersaline environments, indicative of their great adaptive capacities, and demonstrates that they are versatile producers of bioactive compounds. This work will be the basis for the development of future research on the cytotoxic potential of strains of the genera Isoptericola, Ornithinimicrobium, Janibacter, Nesterenkonia, Alkalibacterium, Bacillus, Halomonas, Chromohalobacter, Shewanella, Martelella, Oceanibaculum, Caenispirillum, and Labrenzia. Compounds identified by LC/MS analysis and dereplication were mainly diketopiperazines. However, some other classes of compounds including polyketides and lipopeptides were also observed, showing a promising chemical diversity to be explored.

\section{Additional file}

Additional file 1: Table S1. Cultures conditions for cytotoxic activity screening assays. Table $\mathbf{S 2}$. Physicochemical characteristics of sampling sites in the salt mine in Zipaquirá.

\begin{abstract}
Abbreviations
DKPs: diketopiperazines; LC/MS: liquid chromatography-mass spectrometry; ESI: electrospray ionization; TFA-Na: sodium trifluoroacetate; UV-HPLC-HRMS ultraviolet-high performance liquid chromatography-high resolution mass spectrometry.
\end{abstract}

\section{Authors' contributions}

CD-C, SF, MMZ and SB conceived and designed the study. CD-C, AC, LYR and TS performed the experiments. CD-C and SB wrote the paper. SF, MMZ, JR and FAR reviewed and edited the manuscript. All authors read and approved the final manuscript.

\section{Author details \\ ${ }^{1}$ Unidad de Saneamiento y Biotecnología Ambiental, Departamento de Biología, Pontificia Universidad Javeriana, POB 56710, Bogotá DC, Colombia. ${ }^{2}$ Corporación Corpogen, Carrera 5 \# 66A-34, Bogotá DC, Colombia. ${ }^{3}$ Grupo de Inmunobiología y Unidad de Investigación en Ciencias Biomédicas, Pontificia Universidad Javeriana, POB 56710, Bogotá DC, Colombia. ${ }^{4}$ Grupo de Investi- gación Fitoquímica, Pontificia Universidad Javeriana, POB 56710, Bogotá DC, Colombia. ${ }^{5}$ Departamento de Química, Universidad Nacional de Colombia- Sede Bogotá, Carrera 30 \# 45-03, Bogotá DC, Colombia.}

\section{Acknowledgements}

We thank Fundación MEDINA for its invaluable help in the analysis of secondary metabolite.

\section{Competing interests}

The authors declare that they have no competing interests.

\section{Availability of data and materials}

All datasets supporting the conclusions of the manuscript were included in the manuscript.

\section{Ethics approval and consent to participate}

This article does not contain any studies with human participants or animals performed by any of the authors.

\section{Funding}

This work was supported by grants from the Instituto Colombiano para el Desarrollo de la Ciencia y la Tecnología (Colciencias-Contrato RC 0016-2013), Pontificia Universidad Javeriana and Corpogen. It was done under MAVDT contract No. 0104.

\section{Publisher's Note}

Springer Nature remains neutral with regard to jurisdictional claims in published maps and institutional affiliations.

Received: 1 November 2017 Accepted: 13 December 2017

Published online: 22 December 2017

\section{References}

Aleti G, Sessitsch A, Brader G (2015) Genome mining: prediction of lipopeptides and polyketides from Bacillus and related Firmicutes. Comput Struct Biotechnol J 13:192-203. https://doi.org/10.1016/j.csbj.2015.03.003

APHA/AWWA/WEF (2012) Standard methods for the examination of water and wastewater, 22nd edn. American Public Health Association, Washington, p 1360. ISBN 978-087553-013-0

Bitzer J, Grosse T, Wang L, Lang S, Beil W, Zeeck A (2006) New aminophenoxazinones from a marine Halomonas sp.: fermentation, structure elucidation, and biological activity. J Antibiot 59:86-92. https://doi.org/10.1038/ ja.2006.12

Braña AF, Fiedler HP, Nava H, González V, Sarmiento-Vizcaíno A, Molina A, Acuña JL, García LA, Blanco G (2015) Two Streptomyces species producing antibiotic, antitumor, and anti-inflammatory compounds are widespread among intertidal macroalgae and deep-sea coral reef invertebrates from the Central Cantabrian Sea. Microb Ecol 69:512-524. https://doi. org/10.1007/s00248-014-0508-0

Cayol JL, Ollivier B, Patel BK, Ravot G, Magot M, Ageron E, Grimont PA, Garcia JL (1995) Description of Thermoanaerobacter brockii subsp. lactiethylicus subsp. nov., isolated from a deep subsurface French oil well, a proposal to reclassify Thermoanaerobacter finnii as Thermoanaerobacter brockii subsp. finnii comb. nov., and an emended descrip. Int J Syst Bacteriol 45:783-789. https://doi.org/10.1099/00207713-45-4-783

Chen L, Wang G, Bu T, Zhang Y, Wang Y, Liu M, Lin X (2010) Phylogenetic analysis and screening of antimicrobial and cytotoxic activities of moderately halophilic bacteria isolated from the Weihai Solar Saltern (China). World J Microbiol Biotechnol 26:879-888. https://doi.org/10.1007/ s1 1274-009-0247-4

Claverías FP, Undabarrena A, González M, Seeger M, Cámara B (2015) Culturable diversity and antimicrobial activity of Actinobacteria from marine sediments in Valparaíso bay, Chile. Front Microbiol 6:1-11. https://doi. org/10.3389/fmicb.2015.00737

da Silva FSP, Pylro VS, Fernandes PL, Barcelos GS, Kalks KHM, Schaefer CEGR, Tótola MR (2015) Unexplored Brazilian oceanic island host high salt tolerant biosurfactant-producing bacterial strains. Extremophiles 19:561-572. https://doi.org/10.1007/s00792-015-0740-7

de Cardale-Schrimpff M (1978) No title Breve informe sobre unas excavaciones arqueológicas realizadas en las salinas de Zipaquira, Cundinamarca. Bol Mus del Oro 1:39-41

Demain AL (2014) Importance of microbial natural products and the need to revitalize their discovery. J Ind Microbiol Biotechnol 41:185-201. https:// doi.org/10.1007/s10295-013-1325-z

Dey G, Bharti R, Dhanarajan G, Das S, Dey KK, Kumar BNP, Sen R, Mandal M (2015) Marine lipopeptide Iturin A inhibits Akt mediated GSK3 $\beta$ and FoxO3a signaling and triggers apoptosis in breast cancer. Sci Rep 5:10316. https://doi.org/10.1038/srep10316

Díaz-Cárdenas C, Baena S (2015) Manantiales salinos: inventarios de Diversidad Metabólica y filogenética de microorganismos de ambientes salinos. Rev la Acad Colomb Ciencias Exactas, Físicas y Nat 39:358. https://doi. org/10.18257/raccefyn.199

Elleuch L, Shaaban M, Smaoui S, Mellouli L, Karray-Rebai I, Fourati-Ben Fguira L, Shaaban KA, Laatsch H (2010) Bioactive secondary metabolites from a new terrestrial Streptomyces sp. TN262. Appl Biochem Biotechnol 162:579-593. https://doi.org/10.1007/s12010-009-8808-4

Fdhila F, Vázquez V, Sánchez JL, Riguera R (2003) dd-Diketopiperazines: antibiotics active against Vibrio anguillarum isolated from marine bacteria associated with cultures of Pecten maximus. J Nat Prod 66:1299-1301. https://doi.org/10.1021/np030233e

Fu P, Liu P, Qu H, Wang Y, Chen D, Wang H, Li J, Zhu W (2011) a-Pyrones and diketopiperazine derivatives from the marine-derived actinomycete 
Nocardiopsis dassonvillei hr10-5. J Nat Prod 74:2219-2223. https://doi. org/10.1021/np200597m

Gallardo K, Candia JE, Remonsellez F, Escudero LV, Demergasso CS (2016) The ecological coherence of temperature and salinity tolerance interaction and pigmentation in a non-marine Vibrio isolated from Salar de Atacama. Front Microbiol 7:1-10. https://doi.org/10.3389/fmicb.2016.01943

Gan M, Liu B, Tan Y, Wang Q, Zhou H, He H, Ping Y, Yang Z, Wang Y, Xiao C (2015) Saccharothrixones A-D, tetracenomycin-type polyketides from the marine-derived actinomycete Saccharothrix sp. 10-10. J Nat Prod 78:2260-2265. https://doi.org/10.1021/acs.jnatprod.5b00577

González-Menéndez V, Pérez-Bonilla M, Pérez-Victoria I, Martín J, Muñoz F, Reyes F, Tormo JR, Genilloud O (2016) Multicomponent analysis of the differential induction of secondary metabolite profiles in fungal endophytes. Molecules. https://doi.org/10.3390/molecules21020234

Graça AP, Bondoso J, Gaspar H, Xavier JR, Monteiro MC, de la Cruz M, Oves-Costales D, Vicente F, Lage OM (2013) Antimicrobial activity of heterotrophic bacterial communities from the marine sponge Erylus discophorus (Astrophorida, Geodiidae). PLoS ONE 8(11):e78992. https://doi. org/10.1371/journal.pone.0078992

Gu Q, Fu L, Wang Y, Lin J (2013) Identification and characterization of extracellular cyclic dipeptides as quorum-sensing signal molecules from Shewanella baltica, the specific spoilage organism of Pseudosciaena crocea during $4^{\circ} \mathrm{C}$ storage. J Agric Food Chem 61:11645-11652. https:// doi.org/10.1021/jf403918x

Hall T (1999) BioEdit: a user-friendly biological sequence alignment editor and analysis program for Windows 95/98/NT. Nucleic Acids Symp Ser 41:95-98

Kim PI, Ryu J, Kim YH, Chi YT (2010) Production of biosurfactant lipopeptides Iturin A, fengycin, and surfactin A from Bacillus subtilis CMB32 for control of Colletotrichum gloeosporioides. J Microbiol Biotechnol 20:138-145. https://doi.org/10.4014/jmb.0905.05007

Karthikeyan P, Bhat SG, Chandrasekaran M (2013) Halocin SH10 production by an extreme haloarchaeon Natrinema sp. BTSH10 isolated from salt pans of South India. Saudi J Biol Sci 20:205-212. https://doi.org/10.1016/j. sjbs.2013.02.002

Kim SY, Kim JY, Kim SH, Bae HJ, Yi H, Yoon SH, Koo BS, Kwon M, Cho JY, Lee CE, Hong S (2007) Surfactin from Bacillus subtilis displays anti-proliferative effect via apoptosis induction, cell cycle arrest and survival signaling suppression. FEBS Lett 581(5):865-871. https://doi.org/10.1016/j. febslet.2007.01.059

Kim DH, Kim HK, Kim KM, Kim CK, Jeong MH, Ko CY, Moon KH, Kang JS (2011) Antibacterial activities of macrolactin a and 7-O-succinyl macrolactin a from Bacillus polyfermenticus KJS-2 against vancomycin-resistant enterococci and methicillin-resistant Staphylococcus aureus. Arch Pharm Res 34:147-152. https://doi.org/10.1007/s12272-011-0117-0

Kim J, Shin D, Kim S-H, Park W, Shin Y, Kim WK, Lee SK, Oh K-B, Shin J, Oh D-C (2017) Borrelidins C-E: new antibacterial macrolides from a salternderived halophilic Nocardiopsis sp. Mar Drugs 15:166. https://doi. org/10.3390/md15060166

Lane DJ (1991) 16S/23S rRNA sequencing. In: Stackebrandt E, Goodfellow M (eds) Nucleic acid techniques in bacterial systematics. Wiley, New York, pp 115-175

Mahmoud HM, Kalendar AA (2016) Coral-associated Actinobacteria: diversity, abundance, and biotechnological potentials. Front Microbiol. https://doi. org/10.3389/fmicb.2016.00204

Martins MB, Carvalho I (2007) Diketopiperazines: biological activity and synthesis. Tetrahedron 63:9923-9932

Mata JA, Béjar V, Llamas I, Arias S, Bressollier P, Tallon R, Urdaci MC, Quesada E (2006) Exopolysaccharides produced by the recently described halophilic bacteria Halomonas ventosae and Halomonas anticariensis. Res Microbiol 157(9):827-835. https://doi.org/10.1016/j.resmic.2006.06.004

Nishanth Kumar S, Mohandas C, Siji JV, Rajasekharan KN, Nambisan B (2012) Identification of antimicrobial compound, diketopiperazines, from a Bacillus sp. N strain associated with a rhabditid entomopathogenic nematode against major plant pathogenic fungi. J Appl Microbiol 113:914-924. https://doi.org/10.1111/j.1365-2672.2012.05385.x

O'Connor EM, Shand RF (2002) Halocins and sulfolobicins: the emerging story of archaeal protein and peptide antibiotics. J Ind Microbiol Biotechnol 28:23-31. https://doi.org/10.1038/s//jim/7000190

Ongena M, Jacques P (2008) Bacillus lipopeptides: versatile weapons for plant disease biocontrol. Trends Microbiol 16:115-125
Oren A (2010) Industrial and environmental applications of halophilic microorganisms. Environ Technol 8-9:825-834. https://doi. org/10.1080/09593330903370026

Phelan RW, O'Halloran JA, Kennedy J, Morrissey JP, Dobson ADW, O'Gara F, Barbosa TM (2012) Diversity and bioactive potential of endospore-forming bacteria cultured from the marine sponge Haliclona simulans. J Appl Microbiol 112:65-78. https://doi.org/10.1111/j.1365-2672.2011.05173.x

Raju R, Piggott AM, Conte M, Aalbersberg WGL, Feussner K, Capon RJ (2009) Naseseazines A and B: a new dimeric diketopiperazine framework from a marine-derived actinomycete, streptomyces sp. Org Lett 11:3862-3865. https://doi.org/10.1021/ol901466r

Raskin L, Stromley JM, Rittmann BE, Stahl DA (1994) Group-Specific $16 S$ ribosomal-RNA hybridization probes to describe natural communities of methanogens. Appl Environ Microbiol 60:1232-1240

Regmi SC, Park SY, Kim SJ, Banskota S, Shah S, Kim D-H, Kim J-A (2015) The anti-tumor activity of succinyl macrolactin $A$ is mediated through the $\beta$-Catenin Destruction complex via the suppression of tankyrase and PI3K/Akt. PLoS ONE 10:e0141753. https://doi.org/10.1371/journal. pone. 0141753

Repetto G, del Peso A, Zurita JL (2008) Neutral red uptake assay for the estimation of cell viability/cytotoxicity. Nat Protoc 3:1125-1131. https://doi. org/10.1038/nprot.2008.75

Running W (1993) Computer software reviews. Chapman and Hall dictionary of natural products on CD-ROM. J Chem Inf Comput Sci 33:934-935

Sagar S, Esau L, Hikmawan T, Antunes A, Holtermann K, Stingl U, Bajic VB, Kaur M (2013) Cytotoxic and apoptotic evaluations of marine bacteria isolated from brine-seawater interface of the Red Sea. BMC Complement Altern Med 13:29. https://doi.org/10.1186/1472-6882-13-29

Schultz AW, Oh DC, Carney JR, Williamson RT, Udwary DW, Jensen PR, Gould SJ, Fenical W, Moore BS (2008) Biosynthesis and structures of cyclomarins and cyclomarazines, prenylated cyclic peptides of marine actinobacterial origin. J Am Chem Soc 130:4507-4516. https://doi.org/10.1021/ ja711188x

Shin HJ, Lee H-S, Lee D-S (2010) The synergistic antibacterial activity of 1-acetyl-beta-carboline and beta-lactams against methicillin-resistant Staphylococcus aureus (MRSA). J Microbiol Biotechnol 20:501-505. https:// doi.org/10.4014/jmb.0910.10019

Son S, Ko SK, Jang M, Kim JW, Kim GS, Lee JK, Jeon ES, Futamura Y, Ryoo IJ, Lee JS, Oh H (2016) New cyclic lipopeptides of the iturin class produced by saltern-derived Bacillus sp. KCB14S006. Mar Drugs 14(4):72. https://doi. org/10.3390/md14040072

Stahl DA, Amann R (1991) Development and application of nucleic acid probes in bacterial systematics. In: Stackebrandt E, Goodfellow M (eds) Nucleic acid techniques in bacterial systematics. Wiley, Chichester, pp 205-248

Stein T (2005) Bacillus subtilis antibiotics: structures, syntheses and specific functions. Mol Microbiol 56:845-857

Takashina T, Otozati K, Hamamoto T, Horikoshi K (1994) Isolation of halophilic and halotolerant bacteria from a Japanese salt field and comparison of the partial $16 \mathrm{~S}$ rRNA gene sequence of an extremely halophilic isolate with those of other extreme halophiles. Biodivers Conserv 3:632-642. https://doi.org/10.1007/BF00114206

Tommonaro G, Abbamondi GR, lodice C, Tait K, De Rosa S (2012) Diketopiperazines produced by the Halophilic Archaeon, Haloterrigena hispanica, activate AHL bioreporters. Microb Ecol 63:490-495. https://doi.org/10.1007/ s00248-011-9980-y

van der Merwe E, Huang D, Peterson D, Kilian G, Milne PJ, Van de Venter M, Frost C (2008) The synthesis and anticancer activity of selected diketopiperazines. Peptides 29:1305-1311

Ventosa Ucero A, Quesada Arroquia E, Rodríguez Valera F, Ruiz Berraquero F, Ramos Cormenzana A (1982) Numerical taxonomy of moderately halophilic Gram-negative rods. J Gen Microbiol 128:1959-1968

Ventosa A, Fernández AB, León MJ, Sánchez-Porro C, Rodriguez-Valera F (2014) The Santa Pola saltern as a model for studying the microbiota of hypersaline environments. Extremophiles 18:811-824. https://doi.org/10.1007/ s00792-014-0681-6

Vollenbroich D, Ozel M, Vater J, Kamp RM, Pauli G (1997) Mechanism of inactivation of enveloped viruses by the biosurfactant surfactin from Bacillus subtilis. Biologicals 25:289-297. https://doi.org/10.1006/biol.1997.0099

Walsh CT, Fischbach MA (2010) Natural products version 2.0: connecting genes to molecules. J Am Chem Soc 132:2469-2493 
Widdel F, Kohring G-W, Mayer F (1983) Studies on dissimilatory sulfate-reducing bacteria that decompose fatty acids. Arch Microbiol 134:286-294. https://doi.org/10.1007/BF00407804

Yonezawa K, Yamada K, Kouno I (2011) New diketopiperazine derivatives isolated from Sea Urchin-derived Bacillus sp. Chem PharmBull 59:106-108. https://doi.org/10.1248/cpb.59.106

Zhang L (2005) Integrated approaches for discovering novel drugs from microbial natural products. In: Zhang L, Demain AL (eds) Natural products. Humana Press. https://doi.org/10.1007/978-1-59259-976-9_2
Zhang Q, Li S, Chen Y, Tian X, Zhang H, Zhang G, Zhu Y, Zhang S, Zhang W, Zhang C (2013) New diketopiperazine derivatives from a deep-seaderived Nocardiopsis alba SCSIO 03039. J Antibiot 66:31-36. https://doi. org/10.1038/ja.2012.88

\section{Submit your manuscript to a SpringerOpen ${ }^{\circ}$ journal and benefit from:}

- Convenient online submission

- Rigorous peer review

- Open access: articles freely available online

- High visibility within the field

- Retaining the copyright to your article

Submit your next manuscript at $\boldsymbol{\nabla}$ springeropen.com 